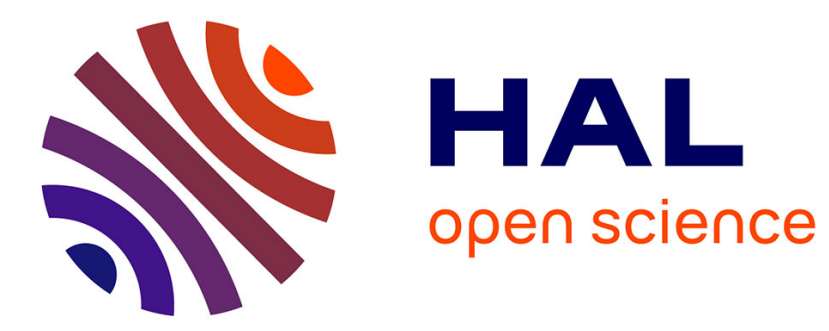

\title{
Gram-Scale Synthesis of a Hexapeptide by Fragment Coupling in a Ball Mill
}

Yves Yeboue, Nadia Rguioueg, Gilles Subra, Jean Martinez, Frédéric Lamaty, Thomas-Xavier Métro

\section{- To cite this version:}

Yves Yeboue, Nadia Rguioueg, Gilles Subra, Jean Martinez, Frédéric Lamaty, et al.. Gram-Scale Synthesis of a Hexapeptide by Fragment Coupling in a Ball Mill. European Journal of Organic Chemistry, 2021, 10.1002/ejoc.202100839 . hal-03348943

\section{HAL Id: hal-03348943 \\ https://hal.science/hal-03348943}

Submitted on 28 Sep 2021

HAL is a multi-disciplinary open access archive for the deposit and dissemination of scientific research documents, whether they are published or not. The documents may come from teaching and research institutions in France or abroad, or from public or private research centers.
L'archive ouverte pluridisciplinaire HAL, est destinée au dépôt et à la diffusion de documents scientifiques de niveau recherche, publiés ou non, émanant des établissements d'enseignement et de recherche français ou étrangers, des laboratoires publics ou privés. 


\title{
Gram-Scale Synthesis of a Hexapeptide by Fragment Coupling in
} a Ball Mill

\author{
Yves Yeboue, ${ }^{[a]}$ Nadia Rguioueg, ${ }^{[a]}$ Gilles Subra, ${ }^{[a]}$ Jean Martinez, ${ }^{[a]}$ Frédéric Lamaty[a]* and Thomas- \\ Xavier Métro[a]*
}

[a] IBMM, Univ Montpellier, CNRS, ENSCM, Montpellier, France

E-mail: frederic.lamaty@umontpellier.fr, thomas-xavier.metro@umontpellier.fr

Homepage URL: https://greenchem.cnrs.fr/

Supporting information for this article is given via a link at the end of the document.

\begin{abstract}
Synthesis of long peptides is generally considered as being a challenge to peptide chemists, in addition to producing significant amounts of toxic waste, such as DMF. Here we show that using solvent-less methods, such as ball milling, enabled the production of the hexapeptide Boc-(Ala-Phe-Gly) ${ }_{2}-\mathrm{OBn}$ at the gram scale with high overall yield ( $77 \%, 5$ linear steps). This is the longest peptide chain synthesized in a ball mill to date, in which the amino acid sequence is precisely controlled. This study complements the current fundamental knowledge required to synthesize longer and more difficult peptide chains (or small proteins) by using peptide fragment couplings in a ball mill.
\end{abstract}

Peptides can be found in many and diverse applications as nutriments, cosmetics and pharmaceuticals. In the field of medicinal chemistry, they can act as therapeutics and diagnostic agents, including to fight the Covid-19 disease. ${ }^{[1]}$ Among the peptide-based drugs, we can highlight Macrilen, which was discovered in our institute (IBMM) in 1999. Macrilen was recently approved by both FDA and EMA as diagnostic test of patients with adult growth hormone deficiency (AGHD), ${ }^{[2]}$ and is actually in phase 2 clinical trial for its use in pediatrics. While the stepwise synthesis of low molecular weight peptides does not generally present any difficulty, the chemical synthesis of longer peptides and proteins is a more challenging task. One of the strategies to their access is the coupling of partially protected peptide fragments. However, when protected peptide fragments are synthesized by SPPS, ${ }^{[3]}$ their hydrophobicity generally increases with the number of side-chain protecting groups and with the size of the fragment, which creates solubility issues and hence synthesis difficulties. These solubility issues are one of the most common challenges encountered by peptide chemists, ${ }^{[4]}$ along with the risk of epimerization of the peptide C-terminal activated amino acid. Indeed, it is common to see solubility issues forcing chemists to modify the synthetic routes to access targeted peptides. ${ }^{[5]}$ The removal of protective groups from amino acid side chains and the use of water as a solvent has allowed native chemical ligation techniques $(\mathrm{NCL})^{[6]}$ to push the limits of these solubility problems. Yet, NCL is still limited by the lack of freedom in the choice of the peptide bond disconnections, and solubility issues are still present for hydrophobic peptide fragments. All these difficulties may also explain why recombinant protein strategy is generally preferred when sequences of more than 60 amino acid residues are targeted. ${ }^{[7]}$ Unfortunately, recombinant protein strategy is also limited by the time required to develop the process, by the dependence of expression systems on the type of peptide and by the production of peptides containing mainly natural amino acids. As a consequence, there is still a large space and need for alternative peptide coupling strategies. Based on our knowledge and on previous studies reported in the literature on peptide synthesis under solvent-less/solvent-free conditions by mechanochemical means, ${ }^{[8]}$ we have considered evaluating the possibility to synthesize long peptides by using a ball mill and a fragment coupling approach. In order to avoid epimerization, tripeptide fragments presenting a C-terminal glycine (Gly) were preferentially selected. In addition, coupling such C-terminal glycine fragments could be a model for the synthesis of collagen oligomer mimics. Indeed, the collagen structures are mainly composed of a tripeptide (X-Y-Gly) repeat in which $X$ or $Y$ represent in most cases proline or hydroxyproline, some structures having alanine or phenylalanine. ${ }^{[9]}$ Although the presence of amino acids bearing aromatic side chains such as phenylalanine is known to destabilize the collagen triple helix, ${ }^{[10]}$ it allows an easy monitoring and optimization of the reactions by HPLC. This is critical for the main objective of this study that is to rapidly access the longest possible peptide chain. For this reason, we aimed at synthesizing oligomers of (Ala-Phe-Gly) $n$, first targeting the monomer Boc-Ala-Phe-Gly-OMe 6 (Scheme 1). Thus, Boc-Phe-OH was reacted with $\mathrm{HCl} \cdot \mathrm{H}-\mathrm{Gly}-\mathrm{OMe}(1.2 \mathrm{eq})$ in a vibratory ball mill (vbm), in the presence of Oxyma (1.2 equiv), $\mathrm{NaH}_{2} \mathrm{PO}_{4} \quad(4.0 \quad$ equiv), $\quad N$-(3-dimethylaminopropyl)- $N$ 'ethylcarbodiimide (EDCl, 1.4 equiv), and EtOAc $(0.11 \mu \mathrm{L} / \mathrm{mg})$ as a liquid additive, following experimental conditions previously described. ${ }^{[8 e]}$ In order to reach the longest (Ala-Phe-Gly) $n$ peptide chain possible, we aimed at synthesizing this first fragment at the gram scale. The coupling was first performed on a total mass of reagents of $9 \mathrm{~g}$, leading to the isolation of $2.2 \mathrm{~g} \mathrm{(91 \%} \mathrm{yield)} \mathrm{of} \mathrm{the}$ expected dipeptide, Boc-Phe-Gly-OMe 1 (Scheme 1). The reaction was performed in a $25 \mathrm{~mL}$ PTFE reactor with one PTFE ball (20 mm diameter). Although we've never observed an incident before, the use of PTFE milling material was preferred over stainless steel for safety reasons. Indeed, the potential formation of sparks arising from violent shock between the balls and the surface of the reactor both made of stainless steel is not desirable when working with liquid additives having a low flash point such as EtOAc (flash point $-4^{\circ} \mathrm{C}$ ). The pure Boc-Phe-GlyOMe 1 was then submitted to gaseous hydrochloric acid for removal of the Boc group. ${ }^{[1]]}$ This solvent-free solid-gas reaction quantitatively yielded the Boc-deprotected peptide $(\mathrm{HCl} \cdot \mathrm{H}-\mathrm{Phe}-$ Gly-OMe 2) as a white powder. 


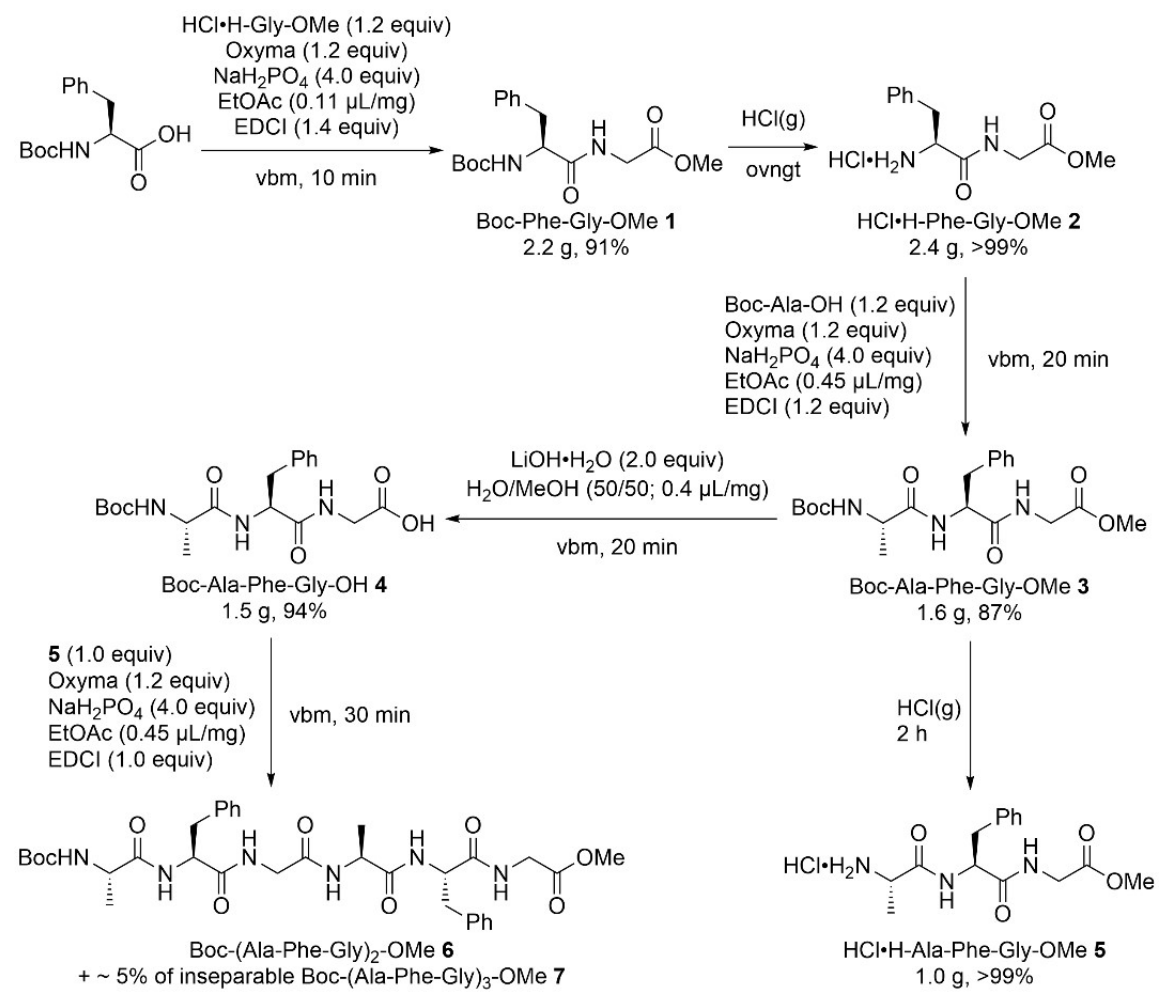

Scheme 1. First strategy to synthesize Boc-(Ala-Phe-Gly $)_{2}-\mathrm{OR}(6 ; \mathrm{R}=\mathrm{Me})$

This peptide was then reacted with Boc-Ala-OH under similar experimental conditions than for the first coupling of Boc-Phe-OH with $\mathrm{HCl} \cdot \mathrm{H}-\mathrm{Gly}-\mathrm{OMe}$, yielding $1.6 \mathrm{~g}$ of the desired tripeptide BocAla-Phe-Gly-OMe 3 (87\% yield). This tripeptide was then submitted to saponification, also performed in a ball mill, using lithium hydroxide monohydrate (2.0 equiv) in the presence of $\mathrm{H}_{2} \mathrm{O} / \mathrm{MeOH}(50 / 50 \mathrm{v} / \mathrm{v} ; 0.4 \mu \mathrm{L} / \mathrm{mg})$ as a liquid additive. This procedure furnished $1.5 \mathrm{~g}$ of Boc-Ala-Phe-Gly-OH 4 after work-up (94\% yield). ${ }^{a,[81,12]}$ Boc-Ala-Phe-Gly-OMe 3 was also submitted to the Boc-deprotection by using gaseous hydrochloric acid producing $1.0 \mathrm{~g}$ of $\mathrm{HCl} \cdot \mathrm{H}-\mathrm{Ala}-\mathrm{Phe}-\mathrm{Gly}-\mathrm{OMe} \mathbf{5}$ in quantitative yield. Next, Boc-Ala-Phe-Gly-OH 4 (1.0 equiv) and $\mathrm{HCl} \cdot \mathrm{H}-A l a-P h e-G l y-$ OMe 5 (1.0 equiv) were reacted together in a ball mill in the presence of Oxyma (1.2 equiv), $\mathrm{NaH}_{2} \mathrm{PO}_{4}$ (4.0 equiv), EtOAc $(0.45 \mu \mathrm{L} / \mathrm{mg})$ and $\mathrm{EDCl}$ (1.0 equiv) for $30 \mathrm{~min}$. Although an LC/MS analysis of the crude revealed the expected hexapeptide Boc(Ala-Phe-Gly) ${ }_{2}-\mathrm{OMe} 6$ was the major compound that formed, this analysis also showed the presence of $\sim 5 \%$ of an impurity with a peak at $958 \mathrm{~m} / \mathrm{z}$, corresponding to the nonapeptide Boc-(Ala-PheGly) ${ }_{3}-\mathrm{OMe}$ 7. Unfortunately, our efforts to separate the hexapeptide Boc-(Ala-Phe-Gly)2-OMe 6 from the undesired nonapeptide Boc-(Ala-Phe-Gly) ${ }_{3}-\mathrm{OMe} \quad 7$ by column chromatography were unsuccessful. Although the mechanism behind the formation of this compound could not be clearly identified, it seemed likely that the fragility of the methyl ester function could be responsible for the formation of this nonapeptide impurity. ${ }^{[13]}$

To address this question, a second strategy was tested: using a benzyl ester instead of the methyl ester, expecting that the benzyl group would be more resistant in our reaction conditions. ${ }^{[14]}$ The synthetic pathway for Boc-(Ala-Phe-Gly)2-OBn 12 was similar to that of Boc-(Ala-Phe-Gly) ${ }_{2}-\mathrm{OMe} 6$. Thus, $\mathrm{HCl} \cdot \mathrm{H}-\mathrm{Ala}-\mathrm{Phe}-\mathrm{Gly}-\mathrm{OBn}$ 11 was obtained in 4 steps in $92 \%$ overall yield from $\mathrm{pTsOH} \cdot \mathrm{H}$ Gly-OBn (Scheme 2). When Boc-Ala-Phe-Gly-OH 4 (1.0 equiv) was reacted with $\mathrm{HCl} \cdot \mathrm{H}-\mathrm{Ala}-\mathrm{Phe}-\mathrm{Gly}-\mathrm{OBn} 11$ (1.1 equiv) in the presence of Oxyma (1.2 equiv), $\mathrm{NaH}_{2} \mathrm{PO}_{4}$ (4.0 equiv), EtOAc $(0.45 \mu \mathrm{L} / \mathrm{mg})$ and $\mathrm{EDCl}$ (1.2 equiv) in a ball mill for $30 \mathrm{~min}, 1.7 \mathrm{~g}$ of the expected hexapeptide Boc-(Ala-Phe-Gly)2-OBn 12 (84\% yield) was isolated, without visible traces of the corresponding nonapeptide impurity. Remarkably, despite the violent impacts of the ball movement in the ball mill reactor, the hexapeptide structure was not degraded. Additionally, the environmental impact of the coupling steps was evaluated by calculating their simple $E$ factor (noted sEF). ${ }^{[15]}$ For each coupling step, the sEF was lower than 5 indicating a low environmental impact, especially when compared to peptide synthesis in solution and on solid support (see SI for details of the SEF values and calculations). ${ }^{[8]}$ In order to access Boc-(Ala-Phe-Gly) $4-\mathrm{OBn}$ by coupling of Boc-(Ala-Phe-Gly) ${ }_{2}-\mathrm{OH}$ with $\mathrm{HCl} \cdot \mathrm{H}-(\text { Ala-Phe-Gly })_{2}-$ $\mathrm{OBn}$, Boc-(Ala-Phe-Gly)2-OBn 12 was submitted to gaseous hydrochloric acid for removal of the Boc group. Yet, a partial hydrolysis of the benzyl group was observed. Unfortunately, we did not succeed to separate the corresponding impurity $\mathrm{HCl} \cdot \mathrm{H}$ (Ala-Phe-Gly) ${ }_{2}-\mathrm{OH}$ from the desired $\mathrm{HCl} \cdot \mathrm{H}-\left(\right.$ Ala-Phe-Gly) ${ }_{2}-\mathrm{OBn}$. We then decided to give up with the collagen oligomer mimic as a target to reach the longest peptide possible by using ball milling. 


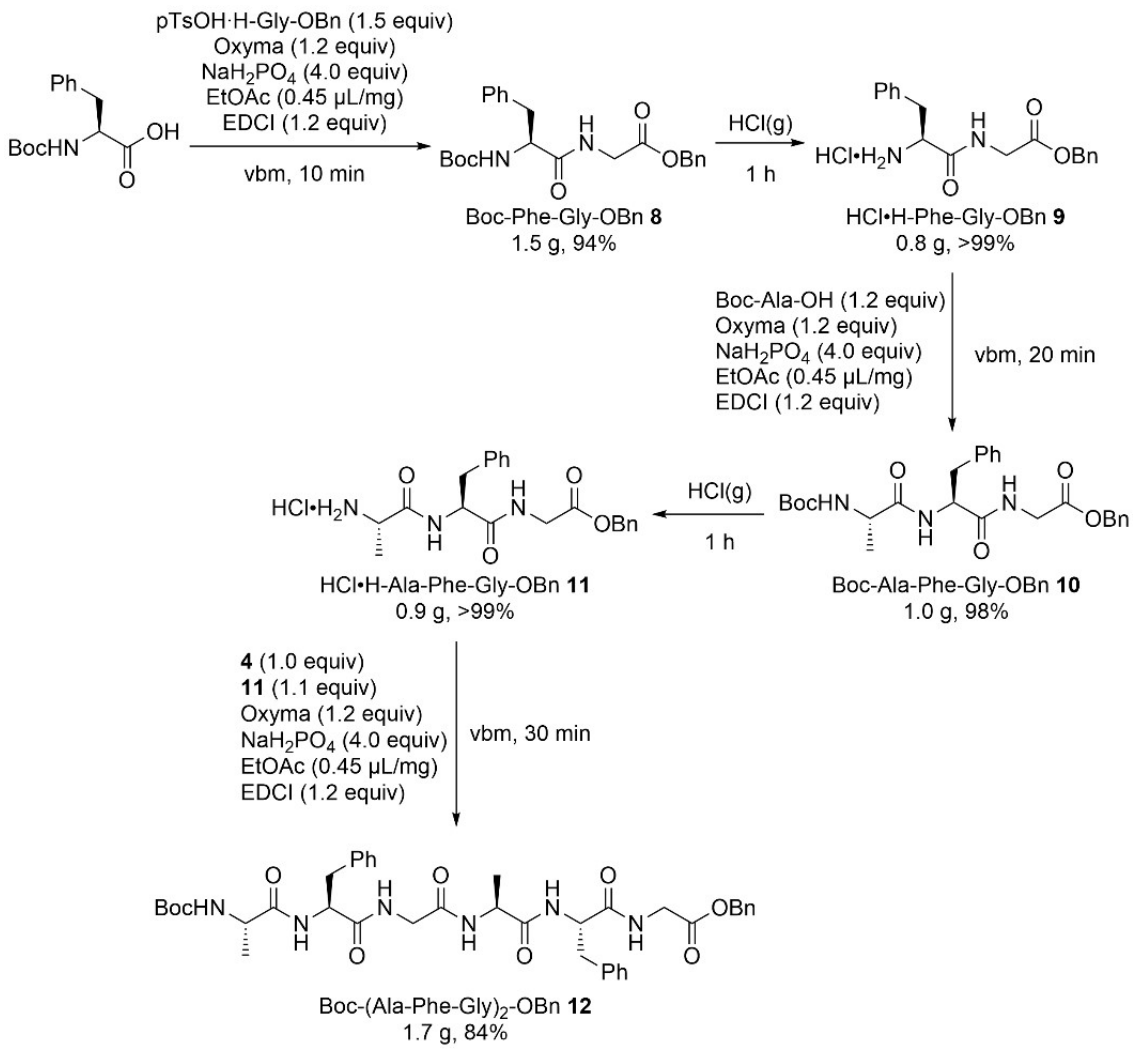

Scheme 2. Second strategy to synthesize Boc-(Ala-Phe-Gly) ${ }_{2}-\mathrm{OR}(\mathbf{1 2} ; \mathrm{R}=\mathrm{Bn})$.

Thus, in hopes of avoiding the hydrolysis of the C-terminal ester, the C-terminal glycine was replaced with amino acids containing a side chain to increase steric hindrance. The corresponding study was published recently and has shown that although this type of amino acid is strongly prone to epimerization during fragment coupling, no epimerization has been observed in these experimental conditions. ${ }^{[8]}$

To conclude, our quest to synthesize the longest peptide chain by using a ball mill led us to test two strategies: Boc/Me and Boc/Bn. The first strategy led to the formation of the hexapeptide Boc-(AlaPhe-Gly)2-OMe 6 together with a nonapeptide impurity, likely related to the fragility of the methyl ester function in our reaction conditions. ${ }^{[13]}$ To overcome this problem, the benzyl ester group was installed as a replacement. Thus, $1.7 \mathrm{~g}$ of the hexapeptide Boc-(Ala-Phe-Gly)2-OBn 12 was isolated in pure form in five linear steps ( $77 \%$ overall yield). To the best of our knowledge, this is the longest peptide chain synthesized in a ball mill, in which the amino acid sequence was precisely controlled. ${ }^{b,}[8 k, 16]$ Together with our recent study on epimerization-free C-term activation of peptide fragments by ball milling, ${ }^{[8]}$ this study lays the fundamental knowledge that will be needed for the synthesis of longer and more difficult peptide chains (or small proteins) by using peptide fragment couplings in a ball mill.

\section{Acknowledgements}

Université de Montpellier, Centre National de la Recherche Scientifique (CNRS), and LabEx CheMISyst (through ANR program ANR-10-LABX-05-01) are acknowledged for financial support.

Keywords: Amino Acids - Ball Mill - Collagen • Mechanochemistry $\cdot$ Peptides

${ }^{a}$ For previous examples of ester hydrolysis in basic conditions in a ball mill, please see references ${ }^{[81,12]}$.

${ }^{b}$ For references describing the synthesis by ball milling of longer peptide chains where the amino acid sequence is not precisely controlled, see references ${ }^{[8 k]}$ and ${ }^{[16]}$.

[1] a) S. Xia, M. Liu, C. Wang, W. Xu, Q. Lan, S. Feng, F. Qi, L. Bao, L. Du, S. Liu, C. Qin, F. Sun, Z. Shi, Y. Zhu, S. Jiang, L. Lu, Cell Res. 2020, 30, 343; b) C. Liu, Q. Zhou, Y. Li, L. V. Garner, S. P. Watkins, L. J. Carter, J. Smoot, A. C. Gregg, A. D. Daniels, S. Jervey, D. Albaiu, ACS Cent. Sci. 2020, 6, 315 .

[2] J. Martinez, J.-A. Fehrentz, Aust. J. Chem. 2020, 73, 334. 
[3] M. Amblard, J.-A. Fehrentz, J. Martinez, G. Subra, in Peptide Synthesis and Applications, Vol. 298 (Ed.: J. Howl), Humana Press, 2005, pp. 3.

[4] M. Paradis-Bas, J. Tulla-Puche, F. Albericio, Chem. Soc. Rev. 2016, 45, 631 .

[5] a) B. L. Bray, Nature Rev. Drug Discov. 2003, 2, 587; b) H. Zhang, S. E. Schneider, B. L. Bray, P. E. Friedrich, N. A. Tvermoes, C. J. Mader, S. R. Whight, T. E. Niemi, P. Silinski, T. Picking, M. Warren, S. A. Wring, Org. Process Res. Dev. 2008, 12, 101; c) A. M. Thayer, Chem. Eng. News 2011, 89, 21; d) T. Zhang, Z. Chen, Y. Tian, B. Han, N. Zhang, W. Song, Z. Liu, J. Zhao, J. Liu, Org. Process Res. Dev. 2015, 19, 1257; e) T. Zhang, W. Song, J. Zhao, J. Liu, Ind. Eng. Chem. Res. 2017, 56, 11697.

[6] a) A. C. Conibear, E. E. Watson, R. J. Payne, C. F. W. Becker, Chem. Soc. Rev. 2018, 47, 9046; b) V. Agouridas, O. El Mahdi, V. Diemer, M. Cargoët, J.-C. M. Monbaliu, O. Melnyk, Chem. Rev. 2019, 119, 7328.

[7] E. R. Lax, T. Shah, in Peptide Therapeutics: Strategy and Tactics for Chemistry, Manufacturing, and Controls, The Royal Society of Chemistry, 2019, pp. 151.

[8] a) V. Declerck, P. Nun, J. Martinez, F. Lamaty, Angew. Chem. Int. Ed. 2009, 48, 9318; b) J. G. Hernández, E. Juaristi, J. Org. Chem. 2010, 75, 7107; c) J. Bonnamour, T.-X. Métro, J. Martinez, F. Lamaty, Green Chem. 2013, 15, 1116; d) T.-X. Métro, E. Colacino, J. Martinez, F. Lamaty, in Ball Milling Towards Green Synthesis:

Applications, Projects, Challenges (Eds.: A. Stolle, B. Ranu), The Royal Society of Chemistry, 2015, pp. 114; e) V. Porte, M. Thioloy, T. Pigoux, T.-X. Métro, J. Martinez, F. Lamaty, Eur. J. Org. Chem. 2016, 3505; f) O. Maurin, P. Verdié, G. Subra, F. Lamaty, J. Martinez, T.-X. Métro, Beilstein J. Org. Chem. 2017, 13, 2087; g) N. Pétry, H. Benakki, E. Clot, P. Retailleau, F. Guenoun, F. Asserar, C. Sekkat, T.-X. Métro, J. Martinez, F. Lamaty, Beilstein J. Org. Chem. 2017, 13, 2169; h) Y. Yeboue, B. Gallard, N. Le Moigne, M. Jean, F. Lamaty, J. Martinez, T.-X. Métro, ACS Sustainable Chem. Eng. 2018, 6, 16001; i) C. Bolm, J. G. Hernández, Chem SusChem 2018, 11, 1410; j) M. Anselmi, P. Stavole, E. Boanini, A. Bigi, E. Juaristi, L. Gentilucci, Future Med. Chem. 2020, 12, 479; k) T. Stolar, S. Grubešić, N. Cindro, E. Meštrović, K. Užarević, J. G. Hernández, Angew. Chem. Int. Ed. 2021, 60, 12727; I) Y. Yeboue, M. Jean, G. Subra, J. Martinez, F. Lamaty, T.-X. Métro, Org. Lett. 2021, 23, 631.

[9] a) B. Brodsky, G. Thiagarajan, B. Madhan, K. Kar Biopolymers 2008, 89, 345; b) M. Gauza-Wlodarczyk, L. Kubisz, D. Wlodarczyk, Int J Biol Macromol 2017, 104, 987.

[10] M. D. Shoulders, R. T. Raines, Annu. Rev. Biochem. 2009, 78, 929 .

[11] R. H. Verschueren, P. Gilles, S. Van Mileghem, W. M. De Borggraeve, Org. Biomol. Chem. 2021, 19, 5782.

[12] a) P. Nun, V. Pérez, M. Calmès, J. Martinez, F. Lamaty, Chem. Eur. J. 2012, 18, 3773; b) V. Strukil, ChemSusChem 2021, 14, 330.

[13] N. William I., B. Fabien, L. Jamie, P. Riley, P. Ian, G. Edouard, B. Claudio, B. Duncan, ChemRxiv 2021 10.26434/chemrxiv.14556153.v1.

[14] P. G. M. Wuts, Editor, Greene's Protective Groups in Organic Synthesis, 5th Edition, Wiley, 2014.

[15] R. A. Sheldon, Green Chem. 2017, 19, 18.

[16] K. J. Ardila-Fierro, D. Crawford, A. Korner, S. James, C. Bolm, J. G. Hernández, Green Chem. 2018, 20, 1262. 


\section{Entry for the Table of Contents}

$$
\text { Solvent-less techniques }
$$

By using solvent-less techniques such as ball milling, a hexapeptide was synthesized at the gram scale without using any toxic solvents. To date, this hexapeptide is the largest precisely controlled amino acid sequence ever synthesized in a ball mill. This study paves the way to future developments for the synthesis of longer peptides (and proteins) by using ball milling. 